\title{
PERFORMANCE AND EMISSIONS CHARACTERISTICS OF CRUDE JATROPHA OIL BIODIESEL BLENDS IN A DIESEL ENGINE
}

\author{
A. Khalid ${ }^{1, a}$, N. Jaat ${ }^{1}$, A. Sapit ${ }^{1}$, A. Razali ${ }^{1}$, B. Manshoor ${ }^{1}$, I. Zaman ${ }^{2}$ and \\ A.A. Abdullah ${ }^{3}$ \\ ${ }^{1}$ Combustion Research Group (CRG) \\ Centre for Energy and Industrial Environment Studies (CEIES) \\ Universiti Tun Hussein Onn Malaysia \\ Parit Raja, Batu Pahat, 86400 Johor, Malaysia. \\ *Email : amirk@uthm.edu.my ${ }^{\mathrm{a}}$ \\ Phone : +6074538484; Fax : +6074536080 \\ ${ }^{2}$ Faculty of Mechanical and Manufacturing Engineering \\ Universiti Tun Hussein Onn Malaysia \\ Parit Raja, Batu Pahat, 86400 Johor, Malaysia \\ ${ }^{3}$ Automotive Engineering Centre, Universiti Malaysia Pahang, \\ 26600 Pekan, Pahang, Malaysia
}

\begin{abstract}
Biofuels based on vegetable oils offer the advantages of being sustainable, annually renewable sources of automobile fuel. Despite many years of improvement, use of vegetable-oil-based fuels still has issues, such as oxidation, the stoichiometric point, bio-fuel composition, antioxidants on degradation and the volume of oxygen compared to diesel. Thus, improvements in the emissions from diesel engines fueled by a blend of crude jatropha oil with diesel could be the requirement to meet the reduced emissions regulations in the future. The purpose of this study is to investigate the effects on the vehicle's performance and exhaust emissions of the combustion process of blended crude jatropha oil and palm oil with different ratios. The engine speed was varied from $1500 \sim 3000 \mathrm{rpm}$, the load test condition was varied from 0 100\% using a Dynapack chassis dynamometer and crude jatropha oil with a diesel blending ratio from 5 15vol\% (CJO5 CJO15) was used. A decrease in $\mathrm{HC}$ emissions was found in the combustion process as the ratio of the blend of crude jatropha oil with diesel was increased and also with nearly equal engine performance. The increase in the jatropha oil biodiesel blending ratio promoted the reduction of $\mathrm{HC}, \mathrm{CO}$ and $\mathrm{CO}_{2}$ emissions in the range $10 \mathrm{vol} \%$ to $15 \mathrm{vol} \%$ of the blends. The improvement in the combustion process with the higher blending ratio is expected to be strongly influenced by the oxygen contained in the blended crude jatropha oil.
\end{abstract}

Keywords: Alternative Fuel; crude jatropha oil; diesel engine; performance; emissions.

\section{INTRODUCTION}

In the new technological era of the world, researchers have put much effort into finding a new alternative fuel to replace diesel in the worldwide automotive industries. There are several reasons for the worldwide concern: first, the rapid decrease in the World's petroleum reserves and the increase in the price of diesel; and second, the increase in environmental concern with regard to global warming and ozone depletion originating 
from exhaust emissions [1,2]. Therefore, alternative sources of fuel have attracted much attention in the automotive industry. Mostly, alternatives are based on vegetableoil-based fuel. The key issues in using this fuel are the oxidation stability, the stoichiometric point, the bio-fuel composition, antioxidants on degradation and the volume of oxygen compared to diesel [3-5]. In addition, although biofuels are more attractive and economical, they create problems of higher emissions compared with petroleum-based diesel[6-8]. This is due to the problems of emitting NOx and particulate matter (PM) into the atmosphere as a result of the oxidation stability, the cetane number, the stoichiometric point, the biofuel composition and the extremely viscous antioxidants on degradation [9]. Thus, improvement in engine exhaust emissions from biodiesel fuel is urgently required to meet the future stringent emissions regulations. It was reported that the biodiesel properties affect the level of combustion, injection timing and spray pattern, thus causing longer injection duration due to the change in the start of injection $[4,5]$. This biodiesel has a high cetane number compared to diesel, less sulfur and contains more oxygen, almost $10 \%$ oxygen by weight. These characteristics are environmentally friendly and can reduce the hydrocarbon (HC), carbon monoxide (CO), and PM emissions in the exhaust gas [10-15]. For these reasons, different studies have been conducted on biodiesel blended with diesel showing that emission concentration $\left(\mathrm{CO}, \mathrm{CO}_{2}, \mathrm{HC}, \mathrm{PM}, \mathrm{NOx}\right)$ varies and it all depends on the source of the biodiesel and the engine combustion system.

The performance of prepared waste frying oil (WFO) was compared with diesel using the four-cylinder compression ignition engine of the Land Rover TDI 110 and the results showed that for $\mathrm{CO}$ and NOx the emissions are lower than those for petroleumbased diesel $[11,12]$. Other than that, preheated crude palm oil (CPO) fuel in the test engine produced higher NOx emissions compared with diesel [16-18]. These effects occur in air ignition and are dependent on the temperature and oxygen concentration, so that the combustion process and exhaust emissions can be clearly observed by examining the different speeds, and included variants of the test load condition to achieve better results. In this research, observation with advance monitoring plays an important role in better understanding the combustion process, combustion characteristics, exhaust emissions and engine performance. Thus, this work provides more knowledge on oxygenating fuel and its effects on combustion characteristics, emissions and performance. This behavior is associated with the relationship between oxygenated fuel and the combustion process, and exhausted emissions.

\section{EXPERIMENTAL SET UP}

The fuels tested were a grade II diesel (STD) and blends of 5 vol\% (CJO5), 10 vol\% (CJO10) and 15 vol\% (CJO15) jatropha oil. The properties of the tested fuels are detailed in Table 1. In this research, the kinematic viscosity of the palm oil blend was measured by a Viscolite 700 model VL700-T15. The density was measured using a Metter Toledo diamond scale model JB703-C/AF. The water content in the biodiesel sample was measured using a Volumetric KF Titrator model v20. The flash point was measured using a Pensky-Martens PMA 4. The engine's fuel consumption was measured with a precision ONOSOKKI model FM2500 volumetric fuel flow meter, pegged between the fuel tank and the fuel pump. The crude jatropha oil was blended with standard diesel in various concentrations to prepare the biofuels. During the blending process, the blending machine was operated at $60^{\circ} \mathrm{C}$ and the mixture was 
stirred at $70^{\circ} \mathrm{C}$ for one hour. The rotating blade speed was adjusted to maintain the same speed at $270 \mathrm{rpm}$. The schematic diagram of the blending process is shown in Figure 1.

Table 1. Properties of the tested fuels.

\begin{tabular}{cccccc}
\hline & \multicolumn{5}{c}{ Properties } \\
\cline { 2 - 6 } Fuel type & $\begin{array}{c}\text { Density } \\
\left(\mathrm{g} / \mathrm{cm}^{3}\right)\end{array}$ & $\begin{array}{c}\text { Kinematic } \\
\text { viscosity }[19]\end{array}$ & $\begin{array}{c}\text { Flash } \\
\text { point }\left({ }^{\circ} \mathrm{C}\right)\end{array}$ & $\begin{array}{c}\text { Water } \\
\text { content }(\%)\end{array}$ & $\begin{array}{c}\text { Acid value } \\
(\mathrm{mg} \mathrm{KOH} / \mathrm{g})\end{array}$ \\
\hline STD & 0.834 & 3 & 80 & 0.00796 & 0.423 \\
CJO5 & 0.851 & 4.6 & 118 & 0.01253 & 0.995 \\
CJO10 & 0.856 & 5.7 & 129 & 0.01321 & 1.687 \\
CJO15 & 0.857 & 5.9 & 131 & 0.01584 & 2.312 \\
\hline
\end{tabular}

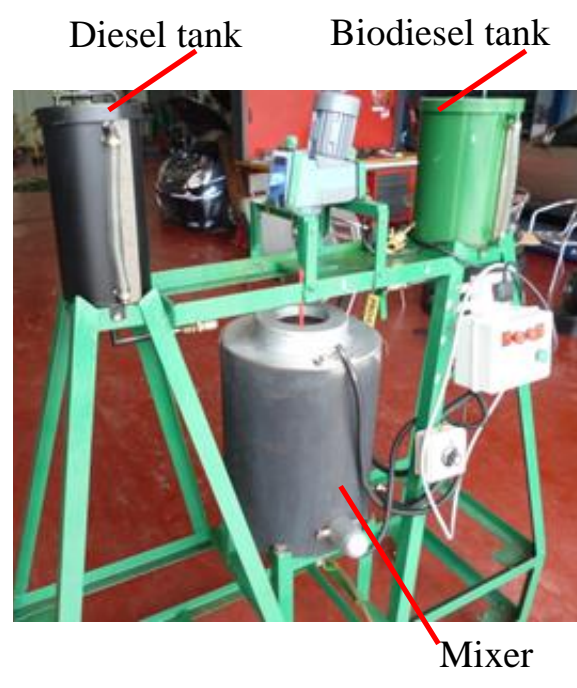

(a) Blending apparatus

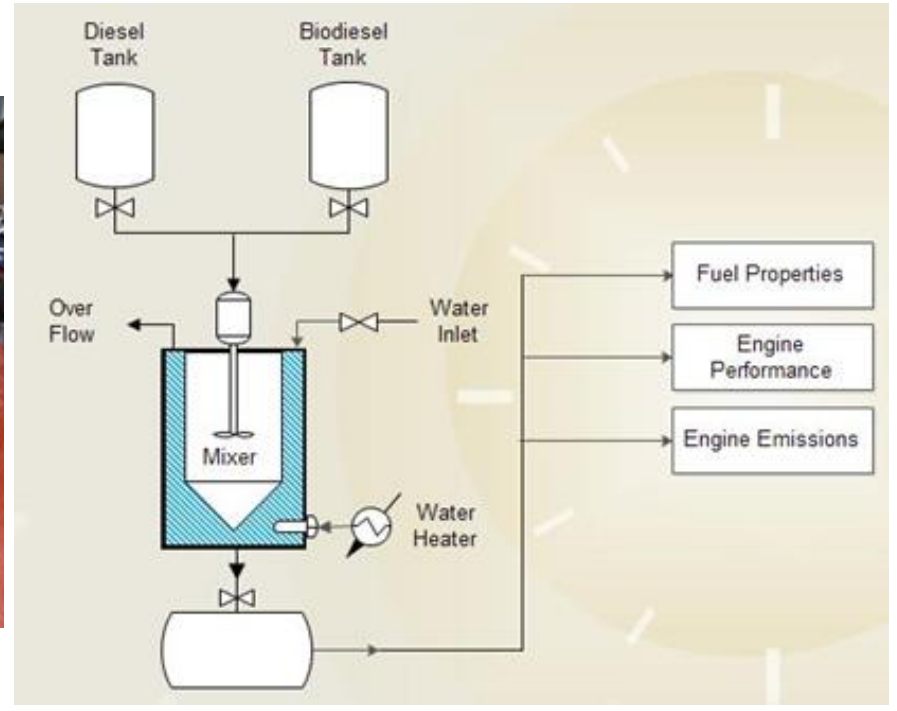

(b) Schematic of blending process

Figure 1. Illustrating the blending process of producing crude jatropha oil blended fuel.

In this experiment, the Mitsubishi PAJERO vehicle was used in order to observe the influence of the fuel properties on the performance and exhaust emissions. This vehicle has a $2467 \mathrm{cc}$ four-cylinder four-stroke cycle engine, model code S-L049GVNTD. The engine is equipped with a turbocharger, capable of maximum power of $62.52 \mathrm{~kW}$ (4200rpm) and has a compression ratio of 21:1. The engine specification, including the operating parameters with fuel injection, is summarized in Table 2. The fuel test is essential in evaluating the fuel consumption pattern of the engine's operation.

The schematic diagram of the experimental setup is shown in Figure 2. To test the performance of this vehicle, an eddy current Dynapack chassis dynamometer able to measure horse power up to $850 \mathrm{HP}$ was used to simulate the wide range engine applications similar to the actual behavior while operating on the road. The engine performance, such as brake power and torque, was measured by this chassis dynamometer. In addition, the engine together with the drive shaft and chassis were 
directly mounted onto the chassis dynamometer through the wheel hub connector as shown in Figure 2(b). There were four different running speeds: $1500 \mathrm{rpm}, 2000 \mathrm{rpm}$, $2500 \mathrm{rpm}$ and $3000 \mathrm{rpm}$. The dynamometer loads considered were 0,50 and $100 \%$. The dynamometer unit load was held fixed at $0 \%$ and $50 \%$ thus covering the typical and middle load range of the combustion behavior. In addition, vehicle performance measurement data comprised the power $(\mathrm{kW})$ and flywheel torque $(\mathrm{Nm})$. Exhaust emissions, such as hydrocarbon $(\mathrm{HC})$, oxygen $\left(\mathrm{O}_{2}\right)$, carbon dioxide $\left(\mathrm{CO}_{2}\right)$, carbon monoxide $(\mathrm{CO})$, and Nitrogen Oxide $\left(\mathrm{NO}_{\mathrm{x}}\right)$ were measured using a Testo 350 portable emission gas analyzer. During operation, sampling probes of the gas analyzer comprising a smoke meter and a gas analyzer were mounted centrally at the end of the engine's exhaust pipe.

Table 2. Detailed specification of the engine.

\begin{tabular}{lc}
\hline \multicolumn{1}{c}{ Items } & Description \\
\hline Type & Mitsubishi \\
Model code & S-L049GV-NTD \\
Engine model & 4D56 (Turbocharger) \\
Engine type & Serial four-cylinder OHC turbo \\
Fuel system & Distribution type jet pump \\
Bore/Stroke $(\mathrm{mm})$ & $91.1 / 95$ \\
Maximum power & $85 \mathrm{ps}(62.25 \mathrm{~kW}) / 4200 \mathrm{rpm}$ \\
Maximum torque & $20.0 \mathrm{~kg}-\mathrm{m}(196 \mathrm{~N}-\mathrm{m}) / 2000 \mathrm{rpm}$ \\
Displacement & $2476 \mathrm{cc}$ \\
Compression ratio & 21 \\
Cooling system & Water cooled \\
\hline
\end{tabular}

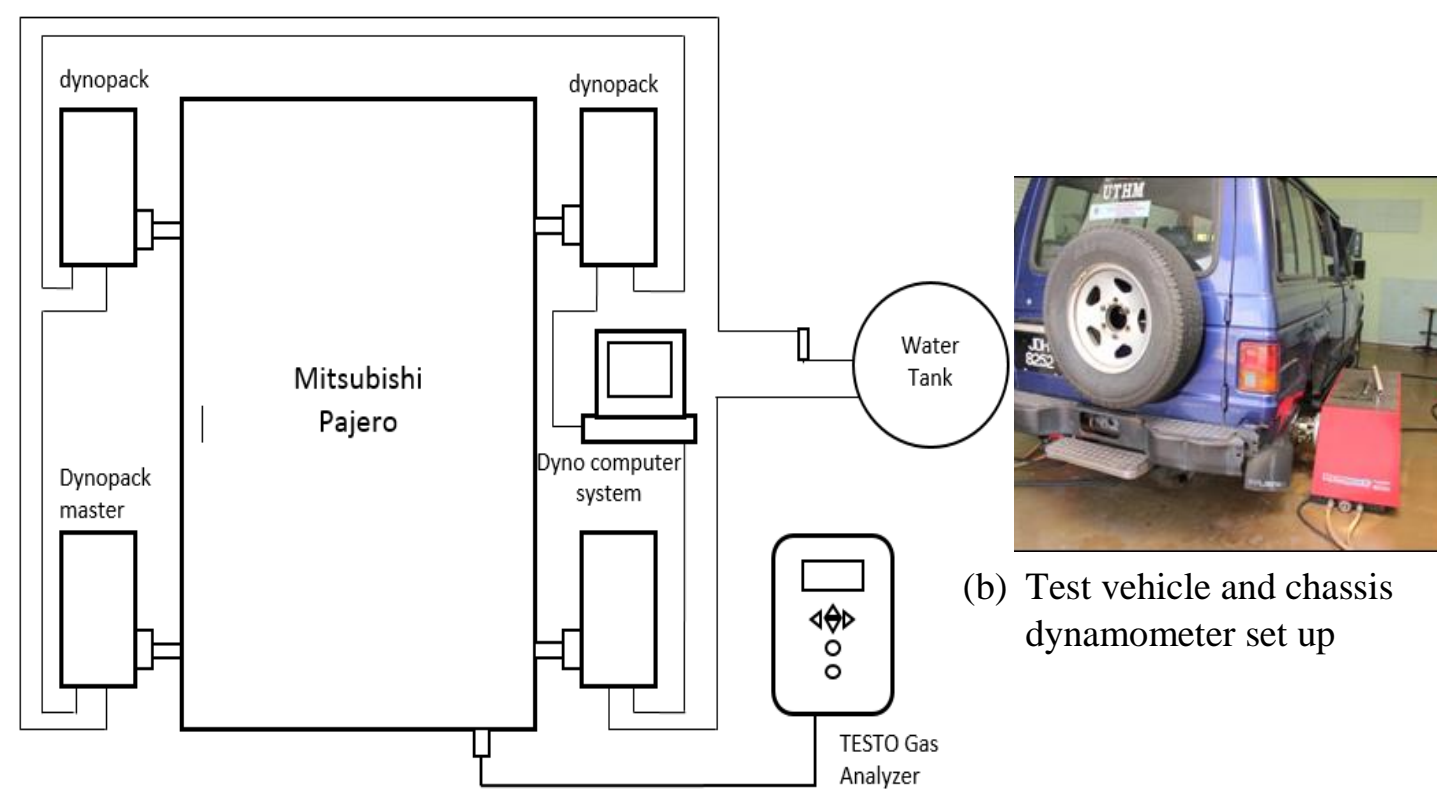

(a) Schematic diagram of experimental setup

Figure 2. Experimental set up. 


\section{RESULTS AND DISCUSSION}

The effect of the jatropha blending ratio on the combustion, exhaust emissions and performance was investigated for the standard diesel (STD), 5 vol\% (CJO5), 10 vol\% (CJO10) and 15 vol\% (CJO15) at engine speeds of 1500, 2000, 2500 and $3000 \mathrm{rpm}$. The performance and emissions were observed under different load conditions of $0 \%$ and $50 \%$ load for all engine operations. Figure 3 shows the relation between the emissions and the engine speed under different blending ratios. As the blending ratio increased up to $15 \mathrm{vol} \%$ for all engine speeds, the exhaust emissions mentioned decreased modestly. It seems that the increasing engine speed under different blending ratios decreased the $\mathrm{HC}, \mathrm{CO}$, and $\mathrm{CO}_{2}$ emissions. With the increase in volume ratio, it seems that fuel consumption also increased so exhibiting relatively weak fuel ignitibility, therefore prolonging the delay in the pilot fuel. The lower HC emissions and smoke opacity might occur due to the lower heating value of the crude jatropha oil blend fuel, despite the significantly higher combustion pressure and temperature [20].

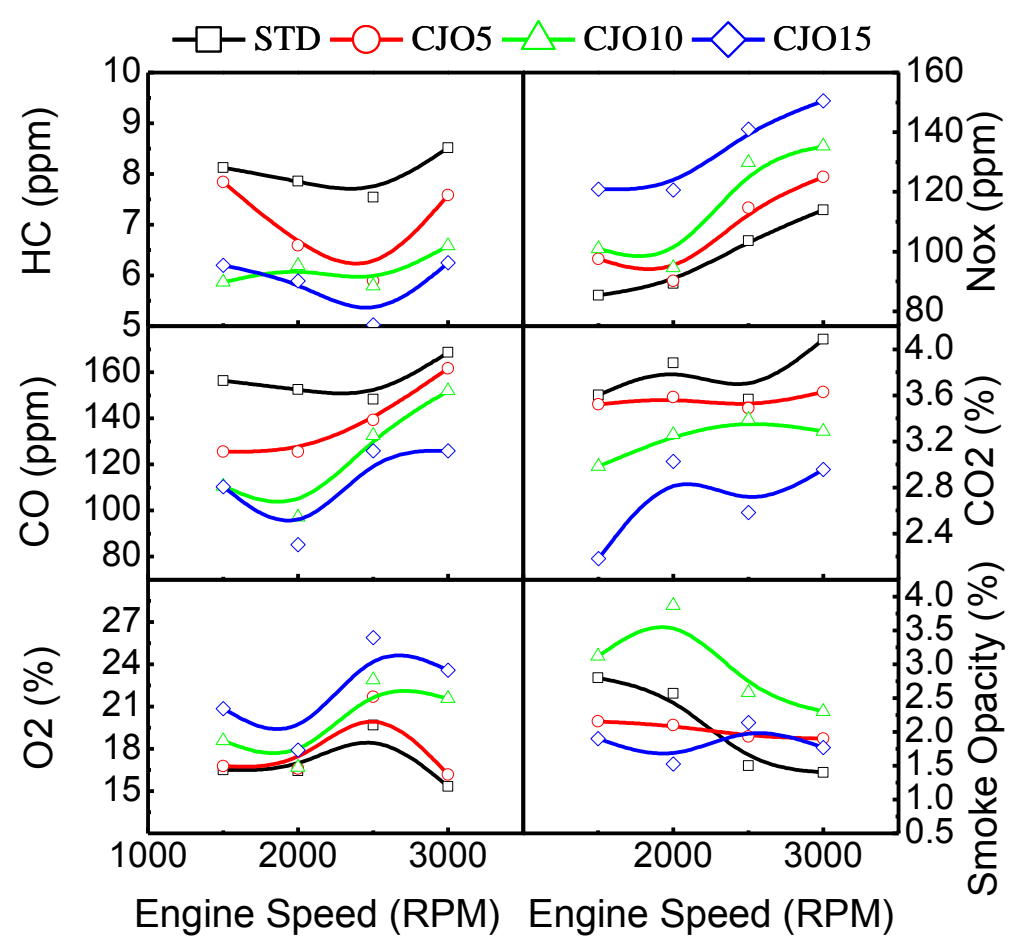

Figure 3. Effects of engine speed on emissions under different blending ratios without load condition.

Performance parameters, such as flywheel torque, torque, brake power and fuel consumption increased as the engine speed increased from $1500 \mathrm{rpm}$ to $3000 \mathrm{rpm}$ under the $0 \%$ load condition and are clearly shown in Figure 4 . Fuel consumption for all CJO blending ratios was higher than that of diesel as the engine speed increased. It seems that the increasing fuel blend ratio of CJO leads to an increase in fuel consumption. However, brake power increased in the same pattern distribution for all CJO blending ratios. When CJO is added to diesel, the oxygen content of the fuel blend is increased and thus better combustion is achieved for CJO and its blends. Meanwhile, there was a slight decrease in the flywheel torque as the CJO blending ratio increased. This may be attributed to the high viscosity of $\mathrm{CJO}$ and the increase in the blend mixture momentum 
[6]. It can be observed that CJO10 has the highest flywheel torque at $3000 \mathrm{rpm}$ among the other CJO blends.

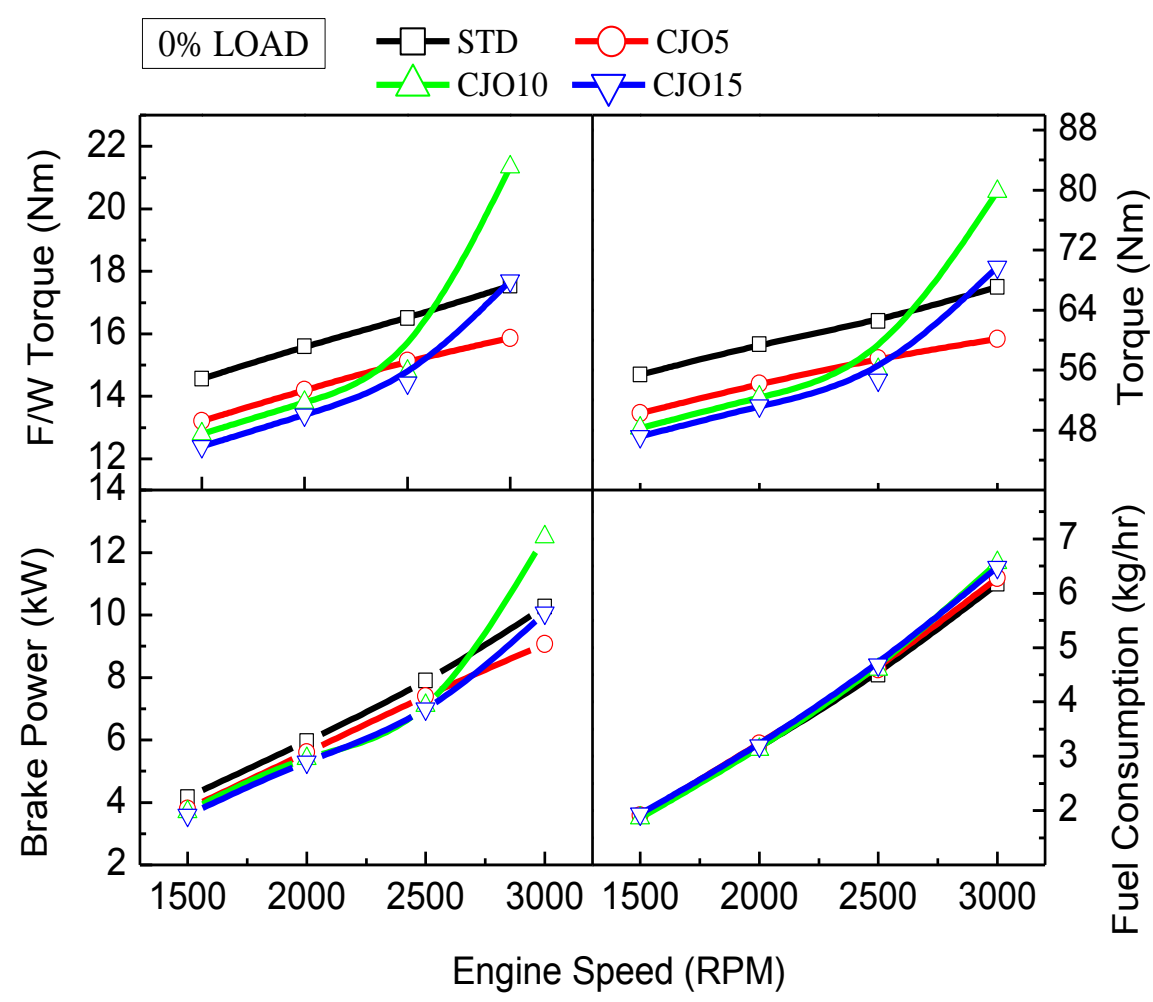

Figure 4. Effects of engine speed on performance under different blending ratios without load conditions

Changes in the jatropha oil blending ratio with different engine speeds and working under high load are clearly observed by examining the engine performance and fuel consumption presented in Figures 5 and 6. Figure 5 shows that CJO15 has the lowest $\mathrm{HC}$ emissions at about $3 \mathrm{ppm}$ and also the lowest $\mathrm{CO}_{2}$ emissions under all engine speeds and load conditions. The NOx emissions increase as the engine speed increases, but if higher blends were to be continued this would result in higher NOx emissions as with CJO15. Meanwhile, STD has the lowest NOx emissions among the tested fuels. The $\mathrm{O}_{2}$ and smoke emissions showed decreasing trends as the speed reached $2500 \mathrm{rpm}$ and above. Meanwhile the $\mathrm{CO}_{2}$ shows an increasing trend as the engine speed increases. The CJO15 also shows the lowest $\mathrm{CO}$ emissions under all load conditions but the level increases at engine speeds above $2000 \mathrm{rpm}$. This behavior could be associated with a difference in the overall combustion process predominantly influencing the emissions reduction [21]. The influences of engine speed are investigated on the point of engine performance. As seen in Figure 6, the brake power is about the same for all CJO blending ratios when applying the 50\% load. A small range of values lies between the fuels under the same engine speed. The performance parameter will increase as the engine speed increases. It clearly shows that the brake power and fuel consumption rate increase proportional to the engine speed for all tested fuel and load conditions. This is due to the same volume of fuel being injected into the combustion chamber. On the other hand, the torque was reduced under all blending ratios compared to the standard diesel. It seems that the lower calorific value of the CJO and its blends lowers the torque produced compared to diesel. 


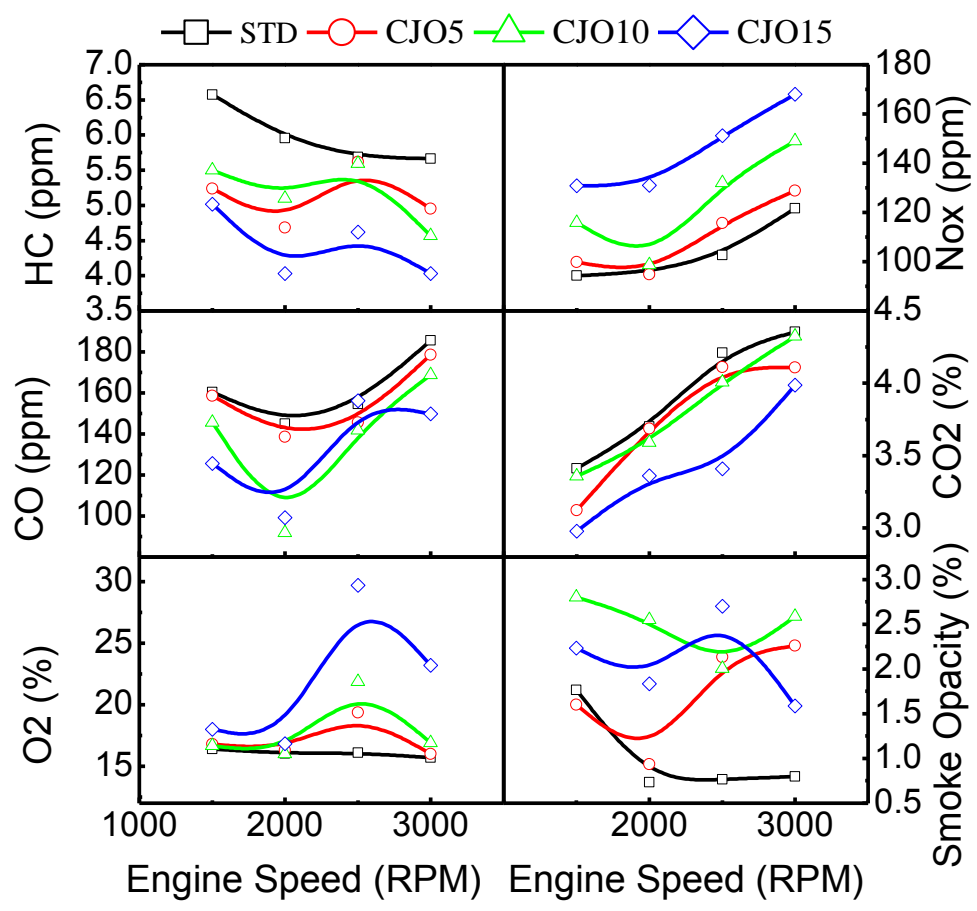

Figure 5. Effects of engine speed on emissions under different blending ratios with medium load ( $50 \%$ load condition)

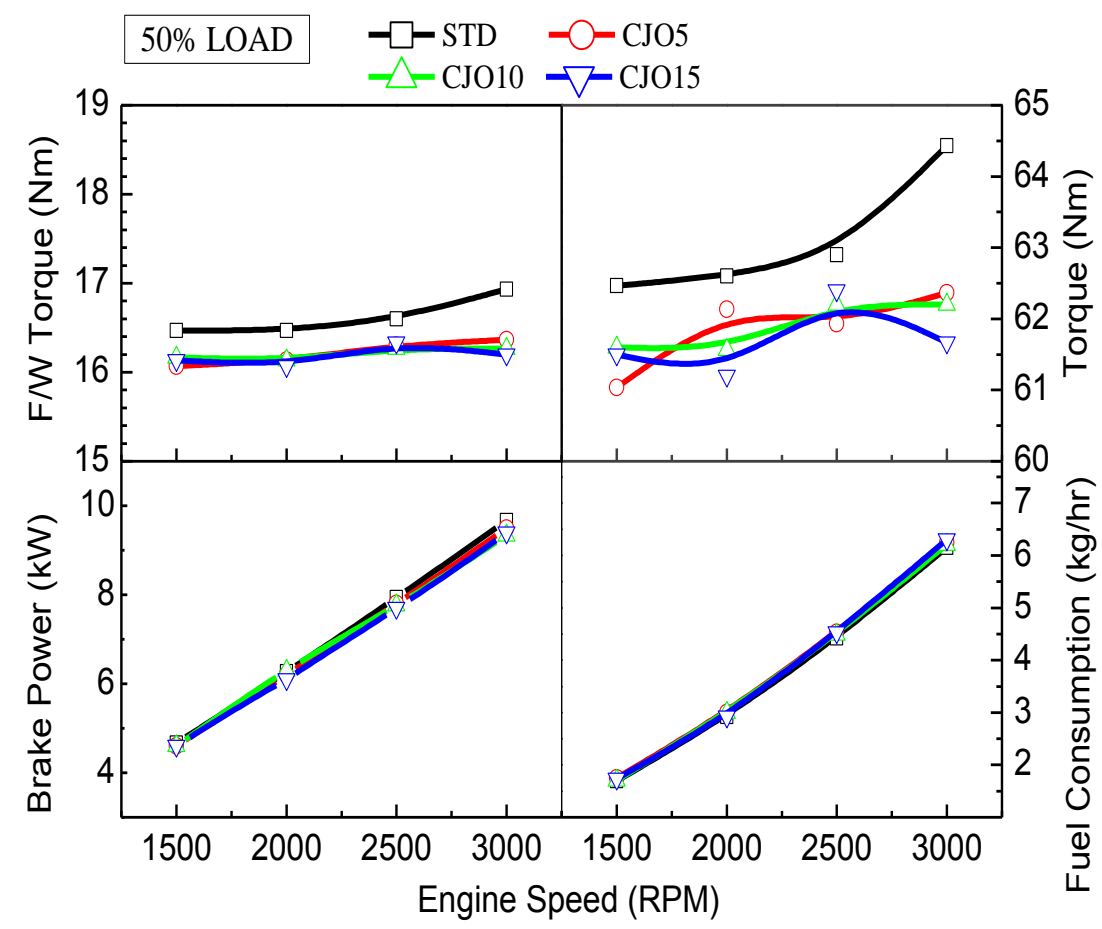

Figure 6. Effects of engine speed on performance under different blending ratios with medium load (50\% load condition).

In this section, the effects of different kinds of biodiesel on engine speed, exhaust emissions and performance are discussed. Other fuels tested were grade II diesel (STD) and blends of B5, B10 and B15 palm oil. To investigate the effect of engine speed on the combustion process, engine speeds of 1500, 2000, 2500 and 
$3000 \mathrm{rpm}$ were employed for all fuels, STD, 5 vol\% (CJO5), 10 vol\% (CJO10), $15 \mathrm{vol} \%$ (CJO15), 5 vol\% (B5), 10 vol\% (B10) and 15 vol\% (B15). The influences of both biodiesel fuels on engine speed were investigated on the point of engine performance and emissions as shown in Figures 7 and 8. As can be seen in Figure 7, the reduction in smoke opacity may be attributed to the oxygen content of the injected fuel at high injection pressure, thus more oxygen content will produce more $\mathrm{C}$ to $\mathrm{CO}$, so indirectly decreasing the smoke emissions while increasing the $\mathrm{CO}$ emissions when the engine speed increases. NOx emissions for all biodiesel CPO blends was higher than those of the CJO blends and diesel. This may be due to the oxygen content in the biodiesel CPO and its blends being higher than in the diesel.

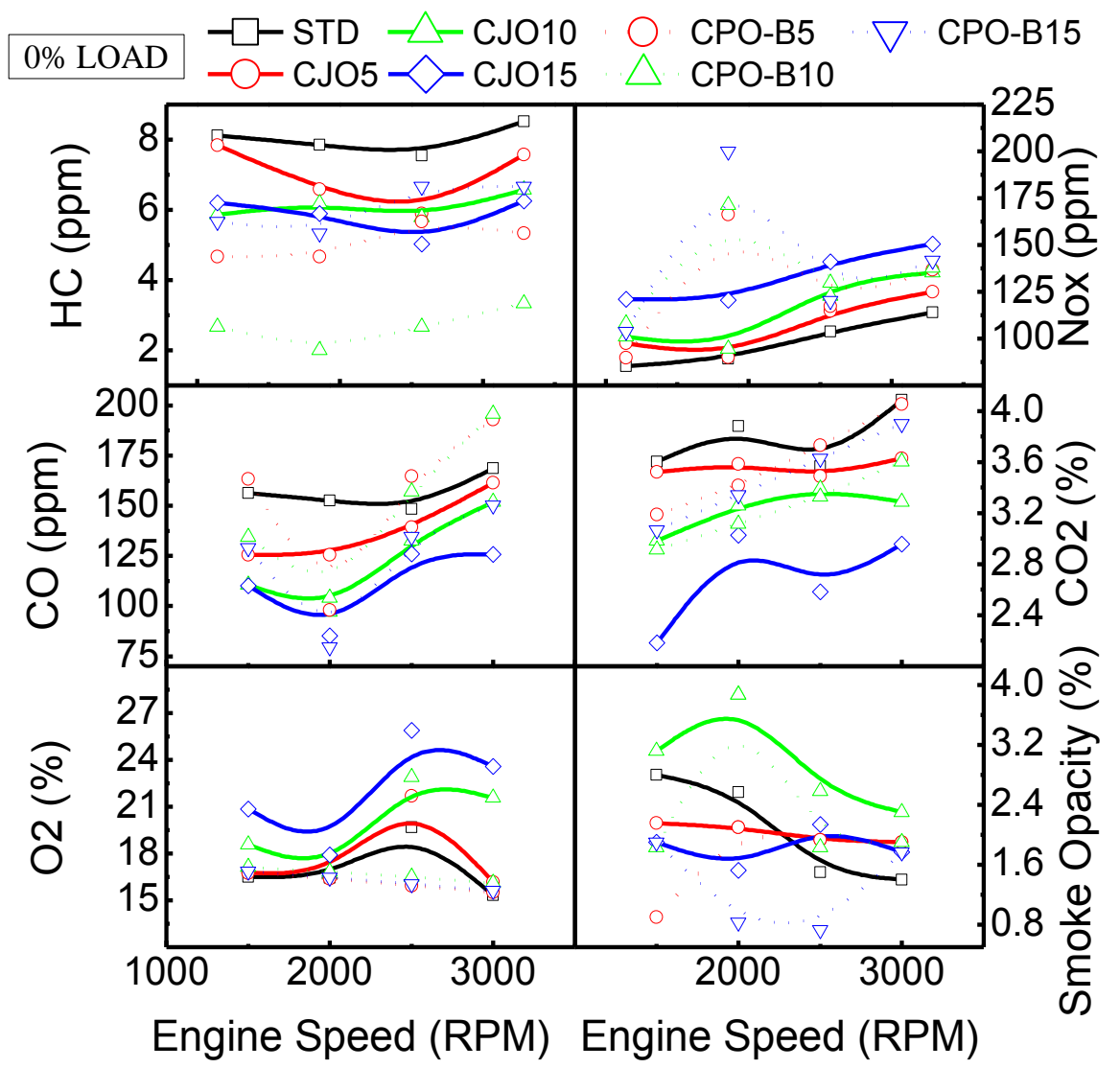

Figure 7. Effects of engine speed on emissions under different blending ratios without load conditions.

Based on the performance data in Figure 8, the brake power was negligibly small and lower for all biodiesel CPO blends compared to all CJO blends and also the diesel, but the brake power will increase as the engine speed increases. This might occur because the density and calorific value of biodiesel CPO blends was lower than the CJO blends. Also, as seen above, the torque of all the biodiesel CPO blends was higher than all the CJO blends. This is because the caloric value of the CJO blends was higher than that of the biodiesel blends. With regard to fuel consumption, it can be seen that this was lower for the biodiesel CPO blends than all the CJO blends but fuel consumption increases as the engine speed increases. 


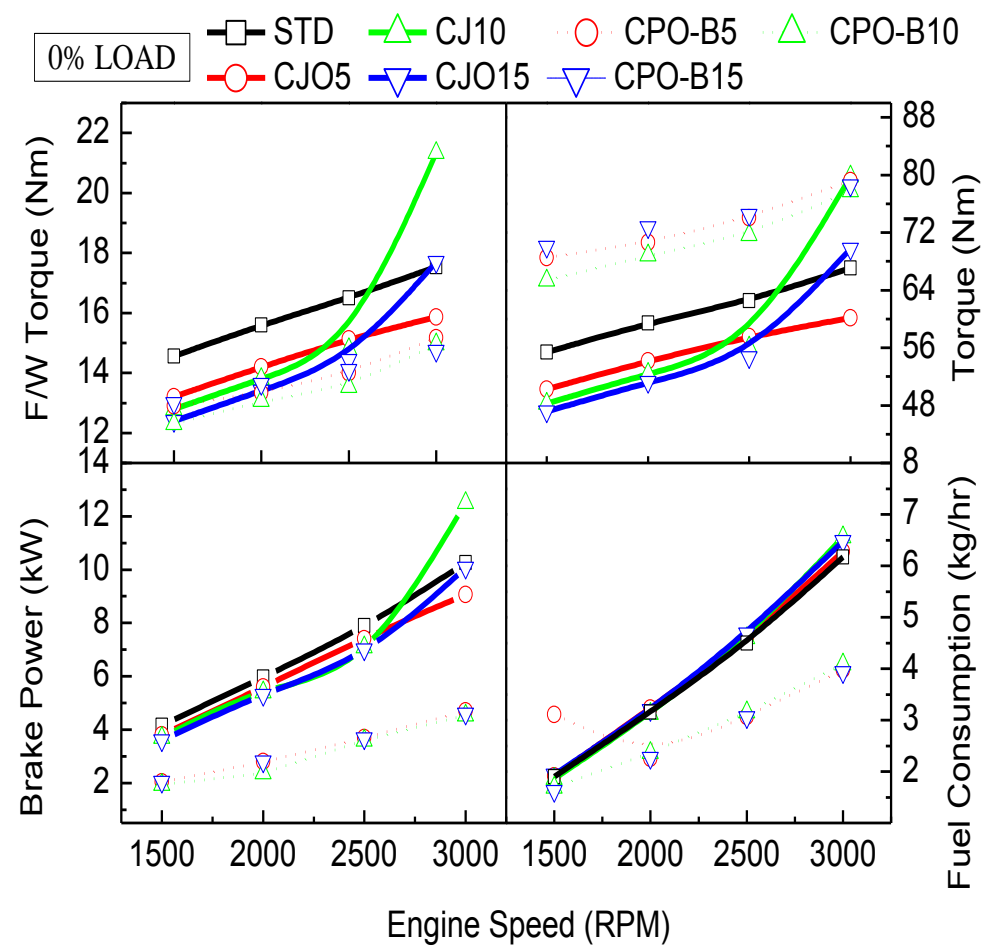

Figure 8. Effects of engine speed on performance under different blending ratios without load conditions.

\section{CONCLUSIONS}

In this case study, the ratio of blended (CJO5, CJO10, CJO15) and standard diesel (STD) operated in a diesel engine under 0 and 50\% load conditions and engine speed was adjusted at 1500, 2000, 2500, $3000 \mathrm{rpm}$. In summary:

1. The deviation in the brake power and the fuel consumption rate for all fuels was small. Both parameters are directly proportional to the increase in engine speed.

2. The increase in the jatropha biodiesel blending ratio promotes a reduction in $\mathrm{HC}$, $\mathrm{CO}$ and $\mathrm{CO}_{2}$ emissions in the blend range $10 \mathrm{vol} \%$ to $15 \mathrm{vol} \%$ due to more oxygen being present during combustion; thus, combustion will become more complete in oxygenated fuel. $\mathrm{CJ} 10$ has the lowest $\mathrm{HC}$ and $\mathrm{CO}_{2}$ emissions and CJO15 has the lowest $\mathrm{CO}$ emissions for all load conditions.

3. NOx emissions are higher for high blends of CJO15 resulting in higher NOx emissions among the tested fuels but these decrease as the engine speed increases. If the engine runs at high speed with an optimum blends ratio emissions will reduce efficiently.

4. The comparison between biodiesel CPO blends and CJO blends shows little difference with lower emissions, but considering the $\mathrm{HC}$, the biodiesel CPO blends produce lower emissions compared to the CJO blends.

\section{ACKNOWLEDGEMENT}

The authors also would like to thank the Ministry of Higher Education Malaysia for supporting this research under the COE-MTUN Grant Scheme VOT.C009 and Fundamental Research Grant Scheme (FRGS) vot.1054. 


\section{REFERENCES}

[1] Krishna MM, Rao VS, Reddy TKK, Murthy P. Comparative studies on performance evaluation of DI diesel engine with high grade low heat rejection combustion chamber with carbureted alcohols and crude jatropha oil. Renewable and Sustainable Energy Reviews. 2014;36:1-19.

[2] Eshton B, Katima JH, Kituyi E. Greenhouse gas emissions and energy balances of jatropha biodiesel as an alternative fuel in Tanzania. Biomass and Bioenergy. 2013;58:95-103.

[3] Yamane K, Ueta A, Shimamoto Y. Influence of physical and chemical properties of biodiesel fuels on injection, combustin and exhaust emission characteristics in a direct injection compression ignition engine. International Journal of Engine Research. 2001;2:249-61.

[4] Khalid A, Mudin A, Jaat M, Mustaffa N, Manshoor B, Fawzi M, et al. Effects of biodiesel derived by waste cooking oil on fuel consumption and performance of diesel engine. Applied Mechanics and Materials. 2014;554:520-5.

[5] Khalid A, Amirnordin SH, Lambosi L, Manshoor B, Sies MF, Salleh H. Spray characteristic of diesel-water injector for burner system. Advanced Materials Research. 2014;845:66-70.

[6] Mat Yasin MH, Mamat R, Sharma KV, Yusop AF. Influence of palm methyl ester (PME) as an alternative fuel in multicylinder diesel engine. Journal of Mechanical Engineering and Sciences. 2012;3:331-9.

[7] Rahim R, Mamat R, Taib MY, Abdullah AA. Influence of fuel temperature on a diesel engine performance operating with biodiesel blended. Journal of Mechanical Engineering and Sciences. 2012;2:226-36.

[8] Nasir N, Daud Z. Performance of Aluminium Sulphate and Polyaluminium Choloride in Biodiesel Wastewater. Journal of Mechanical Engineering and Sciences. 2014;7:1189-95.

[9] Sapit A, Azahari M, Fawzi M, Khalid A, Manshoor B. Effect of air movement to spray development of rapeseed oil in diesel engine. Applied Mechanics and Materials. 2014;554:479-83.

[10] Canakci M. Combustion characteristics of a turbocharged DI compression ignition engine fueled with petroleum diesel fuels and biodiesel. Bioresource technology. 2007;98:1167-75.

[11] Khalid A, Manshoor B. Effect of high swirl velocity on mixture formation and combustion process of diesel spray. Applied Mechanics and Materials. 2012;229:695-9.

[12] Elango T, Senthilkumar T. Performance and emission characteristics of CI engine fuelled with non edible vegetable oil and diesel blends. Journal of Engineering Science and Technology. 2011;6:240-50.

[13] Abbaszadeh A, Ghobadian B, Najafi G, Yusaf T. An experimental investigation of the effective parameters on wet washing of biodiesel purification. International Journal of Automotive and Mechanical Engineering. 2014;9:152537.

[14] Rostami S, Ghobadian B, Kiani Deh Kiani M. Effect of the injection timing on the performance of a diesel engine using Diesel-Biodiesel blends. International Journal of Automotive and Mechanical Engineering. 2014;10:1945-58. 
[15] Vashist D, Ahmad M. Statistical Analysis of Diesel Engine Performance for Castor and Jatropha Biodiesel-Blended Fuel. International Journal of Automotive and Mechanical Engineering. 2014;10:2155-69.

[16] Buyukkaya E. Effects of biodiesel on a DI diesel engine performance, emission and combustion characteristics. Fuel. 2010;89:3099-105.

[17] Utlu Z, Koçak MS. The effect of biodiesel fuel obtained from waste frying oil on direct injection diesel engine performance and exhaust emissions. Renewable Energy. 2008;33:1936-41.

[18] Kalam M, Masjuki H. Biodiesel from palmoil—an analysis of its properties and potential. Biomass and Bioenergy. 2002;23:471-9.

[19] CPG (Comp Performance Group). 2012.

[20] Chauhan BS, Kumar N, Cho HM. A study on the performance and emission of a diesel engine fueled with Jatropha biodiesel oil and its blends. Energy. 2012;37:616-22.

[21] Ganapathy T, Gakkhar R, Murugesan K. Influence of injection timing on performance, combustion and emission characteristics of Jatropha biodiesel engine. Applied energy. 2011;88:4376-86. 